\title{
Resistance of bovine gastrointestinal nematodes to four classes of anthelmintics in the semiarid region of Paraíba state, Brazil
}

\author{
Resistência de nematódeos gastrintestinais de bovinos à quatro classes de \\ anti-helmínticos no semiárido do Estado da Paraíba, Brasil
}

\begin{abstract}
Lídio Ricardo Bezerra de Melo (D); Luana Carneiro de Sousa² (D); Clarisse Silva de Menezes Oliveira² (D); Felipe Boniedj Ventura Alvares² (D); Larissa Claudino Ferreira1 (1); Roberto Alves Bezerra ${ }^{1}$ (D); Ana Célia Rodrigues Athayde ${ }^{1}$ (D); Thais Ferreira Feitosa ${ }^{2}$ (D); Vinícius Longo Ribeiro Vilela ${ }^{1,2 \star}$ (i)
\end{abstract}

'Programa de Pós-graduação em Ciência e Saúde Animal, Universidade Federal de Campina Grande - UFCG, Patos, PB, Brasil 2Departamento de Medicina Veterinária, Instituto Federal de Educação, Ciência e Tecnologia da Paraíba - IFPB, Sousa, PB, Brasil

How to cite: Melo LRB, Sousa LC, Oliveira CSM, Alvares FBV, Ferreira LC, Bezerra RA, et al. Resistance of bovine gastrointestinal nematodes to four classes of anthelmintics in the semiarid region of Paraíba state, Brazil. Braz J Vet Parasitol 2021; 30(3): e010921. https://doi.org/10.1590/S1984-29612021077

\begin{abstract}
The effectiveness of four anthelmintic classes on cattle gastrointestinal nematodes in the semi-arid region of Paraiba State, Brazil, was evaluated. Twenty farms were used, testing 40 animals in each one, totaling 800 animals. Cattle were divided into four groups composed with ten animals: I, treated with albendazole sulfoxide 15\%; II, treated with ivermectin 1\%; III, treated with closantel 25\%; IV, treated with levamisole hydrochloride $7.5 \%$. All treatments were administered subcutaneously. For the Fecal Egg Count Reduction Test (FECRT), individual fecal samples were collected on days 0 and 14, and sent for analysis of egg count per gram of feces (EPG) and larval cultures. It was observed that multiresistance was present in $95 \%$ (19/20) of the farms. Resistance to ivermectin and albendazole was observed in 95\% (19/20), to closantel in $75 \%(15 / 20)$ and to levamisole in $20 \%(4 / 20)$. The most used management system was semi-intensive $(75 \% ; 15 / 20)$ and the ivermectin was the most reported drug for controlling helminths $(65 \% ; 13 / 20)$. Haemonchus spp. was the most prevalent helminth genus. It was concluded that the anthelmintic resistance of bovine gastrointestinal nematodes is high in the semi-arid of Paraíba State, Brazil, with multiresistance observed mainly to ivermectin, albendazole and closantel.
\end{abstract}

Keywords: Antiparasitics, helminthiasis, multiresistance, ruminants.

\begin{abstract}
Resumo
Avaliou-se a eficácia de quatro classes de anti-helmínticos sobre nematódeos gastrintestinais de bovinos na região semiárida da Paraíba, Brasil. Foram utilizadas 20 fazendas, sendo testados 40 animais em cada uma, totalizando 800 animais. Os bovinos foram distribuídos em quatro grupos compostos por dez animais: I, tratado com sulfóxido de albendazol 15\%; II, tratado com ivermectina 1\%; III, tratado com closantel 25\%; IV, tratado com cloridrato de levamisole 7,5\%. Para o Teste de Redução da Contagem de Ovos Fecais (TRCOF), amostras fecais individuais foram coletadas nos dias 0 e 14 e enviadas para análises de contagem de ovos por grama de fezes (OPG) e coproculturas. Observou-se que a multirressistência estava presente em 95\% (19/20) das fazendas. Foi observada resistência à ivermectina e ao albendazol, em 95\% das fazendas (19/20); ao closantel, em 75\% (15/20) e, ao levamisole, em $20 \%$ (4/20). O sistema de manejo mais utilizado foi o semi-intensivo (75\%; $15 / 20$ ) e a ivermectina foi o fármaco mais relatado para controle de verminose $(65 \% ; 13 / 20)$. O gênero de helminto mais prevalente foi Haemonchus spp. (76,7\%). Conclui-se que é alta a resistência anti-helmíntica por nematódeos gastrintestinais de bovinos no Semiárido da Paraíba, Brasil, com multirressistência observada principalmente à ivermectina, ao albendazol e ao closantel.
\end{abstract}

Palavras-chave: Anti-parasitários, helmintoses, multirressistência, ruminantes.

Received June 11, 2021. Accepted August 19, 2021

*Corresponding author: Vinícius Longo Ribeiro Vilela. E-mail: vinicius.vilela@ifpb.edu.br

This is an Open Access article distributed under the terms of the Creative Commons Attribution License, which permits unrestricted use distribution, and reproduction in any medium, provided the original work is properly cited. 


\section{Introduction}

Brazil stands out among the milk and beef-producing countries, with the fastest-growing agribusiness in the world. This country finished 2020 with a record final balance of US $\$ 87.7$ billion, which contributed positively and decisively to the total trade balance (Kreter et al., 2021). In this country, the profitability of livestock activities can be significantly reduced by the effects of parasites, which affect the welfare and productivity of cattle. Infections with gastrointestinal nematodes have an annual economic impact of 7.11 billion dollars (Grisi et al., 2014).

The main genera of nematodes that parasitize cattle are Haemonchus spp., Trichostrongylus spp., Cooperia spp., belonging to the Trichostrongylidae family; Oesophagostomum sp., belonging to the Strongylidae family; Strongyloides sp., to the Strongyloididae family; and Trichuris spp., to the Trichuridae family. In cattle, the parasitic infection occurs under ideal temperature and humidity conditions, and transmission occurs during the ingestion of pasture contaminated with infective larvae, which, in the animal's gastrointestinal tract, become adults, reaching reproductive maturity, reproducing and eliminating their eggs in the environment through feces (Bowman, 2010; Neves, 2014). This cycle is completed around 28 to 35 days. However, the infecting larvae can remain in the environment for a few months (Taylor et al., 2013). Usually, cattle nematode infections are mixed, in which more than one species parasitizes the same animal (Fávero et al., 2020). The absence of adequate anthelmintic control can lead to significant losses, which gives rise to decreased food intake, gastrointestinal disorders and impaired animal development, leading to death in extreme cases (Cezar et al., 2008; Almeida et al., 2020).

To avoid losses relating to helminth infections, the main means of control is through use of chemical compounds with a broad spectrum of activity, mainly comprising macrocyclic lactones, benzimidazoles, imidazothiazoles and salicylanilides (Taylor et al., 2013; Silva et al., 2017; Ramos et al., 2020). Most of the time, these are administered without applying any technical criteria for drug selection, in an empirical and indiscriminate manner. This has additional implications for the effectiveness of anthelmintic treatments, since it causes the emergence and dissemination of parasitic resistance (Neves et al., 2014; Geurden et al., 2015. Ramos et al., 2018; 2020).

The resistance of bovine gastrointestinal nematodes to most drugs available on the market has become an emerging problem worldwide (O'Shaughnessy et al., 2014; Rose et al., 2015; Berk et al., 2016; Lobayan et al., 2017; Baiak et al., 2019). In several countries, there are high rates of resistance, such as in New Zealand (Leathwick \& Luo, 2017), Australia (Bullen et al., 2016), Germany, Belgium and Sweden (Demeler et al., 2009), Sudan (Mohammedsalih et al., 2021), United States (Gasbarre, 2014) and Argentina (Cristel et al., 2017). In Brazil, there have been reports of resistance to benzimidazoles (Ramos et al., 2020; Fávero et al., 2020), macrocyclic lactones (Neves et al., 2014; Borges et al., 2015; Ramos et al., 2020), imidazothiazoles (Neves et al., 2014; Ramos et al., 2020) and salicylanilides (Silva et al., 2017; Ramos et al., 2020).

In the semiarid region of Brazil, information about the effectiveness of anthelmintics is scarce. Therefore, the objective of the present study was to obtain more information on anthelmintic resistance in cattle in the semiarid region of the state of Paraíba, northeastern Brazil. The efficacy of injectable formulations of albendazole sulfoxide, ivermectin, closantel and levamisole hydrochloride was evaluated in naturally infected cattle in 20 farms from 20 different municipalities across the state of Paraíba.

\section{Material and Methods}

\section{Ethical approval and location of the study}

This study was approved by our institution's research ethics committee, under registration number 23000.000663.2019-81.

It was carried out in the semi-arid region of the state of Paraíba, northeastern Brazil. This area forms part of the Caatinga biome. Its rains are irregular and are concentrated in the months from January to May, with average annual precipitation between 250 and $800 \mathrm{~mm}$. The average maximum temperature is $32{ }^{\circ} \mathrm{C}$ and the average minimum temperature is $20^{\circ} \mathrm{C}$. There are high rates of evaporation and the relative humidity of the air is around 70\% (IBGE, 2019).

Fecal samples were collected between January and December 2020, on 20 cattle farms that had herds of more than 40 animals, with a history of problems with nematode control or indiscriminate anthelmintic use, and on which the cattle had not been dewormed for at least 90 days. Each farm was located in a different municipality, as shown in Figure 1. 


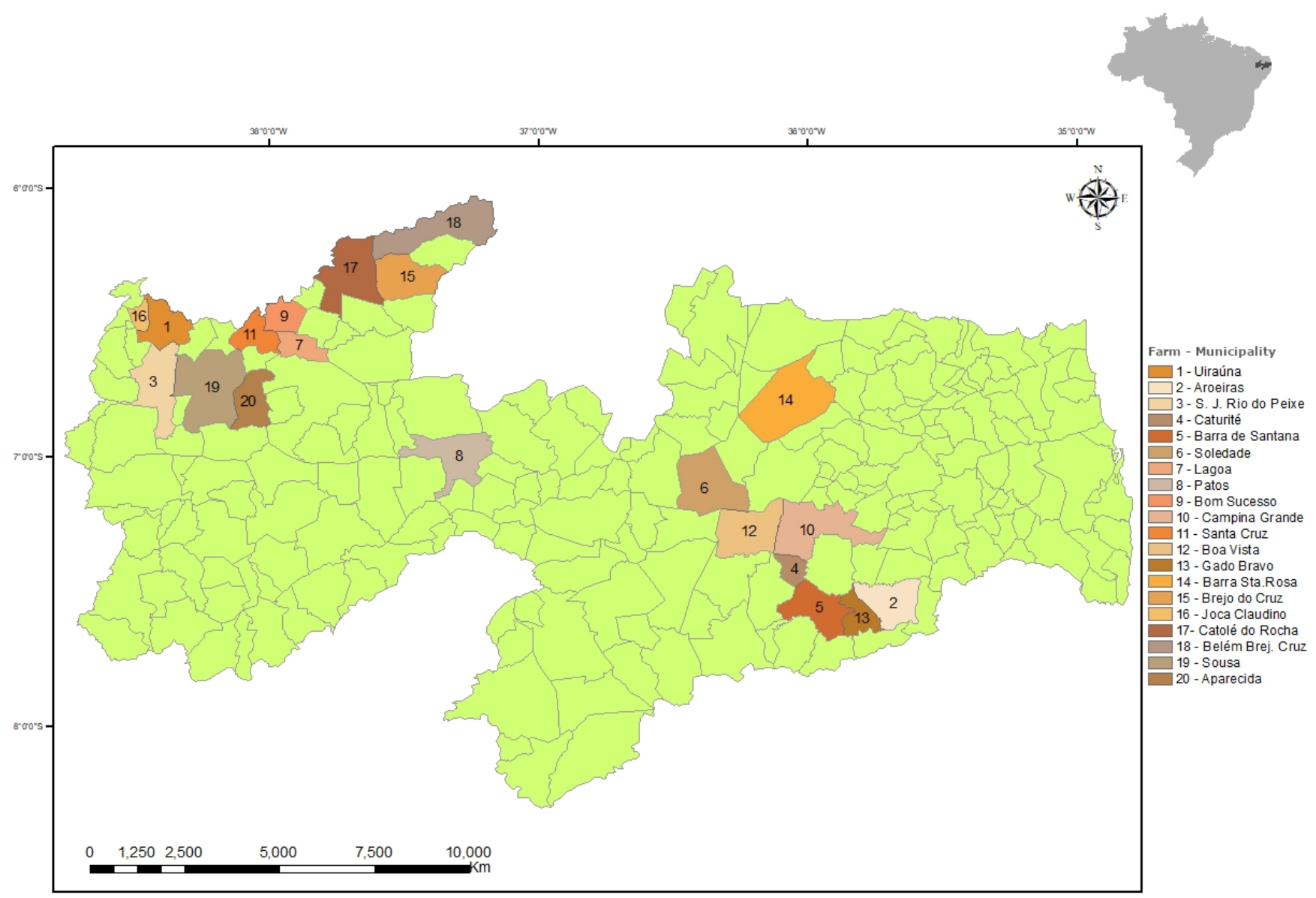

Figure 1. Geographical distribution of the municipalities in which farms were visited for undertaking anthelmintic resistance tests on bovine gastrointestinal nematodes, in the semiarid region of Paraíba state, Brazil.

\section{Diagnosis of anthelmintic resistance}

On each farm, 40 naturally infected animals were used, of both sexes, aged between four months and eight years, regardless of breed. These 40 animals had an egg count per gram of feces (EPG) $\geq 150$. Subsequently, the animals were identified individually through ear tags and were randomly distributed into four groups composed of ten animals each: group I, treated with albendazole sulfoxide 15\% (3.4 mg / kg) (Agebendazol®, Agener União); group II, treated with ivermectin $1 \%(0.2 \mathrm{mg} / \mathrm{kg}$ ) (Ivomec $®$, Boehringer Ingelheim); group III, treated with closantel $25 \%$ (5 mg / kg) (Taitec ${ }^{\circledR}$, Calbos); group IV, treated with levamisole hydrochloride 7.5\% (3.75 mg / kg) (Ripercol®, Zoetis). Prior to the treatments, all animals underwent weight estimation by means of a weighing tape (Fita Torácia

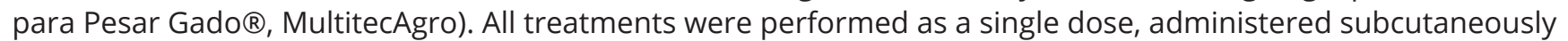
after previous antisepsis of the application site, in accordance with the manufacturers' recommendations.

Fecal samples were collected individually and directly from the rectal ampoule, on the same day, before the anthelmintic treatment (day 0) and 14 days after (day 14) (FAO, 2004). Subsequently, these were placed in plastic bags, labeled, kept refrigerated in an isothermal box and promptly sent to the Veterinary Parasitology Laboratory (VPL) of the Instituto Federal da Paraíba (IFPB), Sousa, Paraíba, for analysis.

EPG counts were performed by a McMaster modified technique (Gordon \& Whitlock, 1939), with a sensitivity of 50 EPG. Larval cultures (Roberts \& O'Sullivan, 1950) were carried out per group and per collection, from a pool of samples. However, when the mean EPG was zero in a given group on day 14, larval cultures were not performed.

Were used eggCounts package version 2.3, which is a " $R$ " package developed to analyze faecal egg count reduction using Bayesian hierarhical models (Wang \& Paul, 2018). The percentage efficacy was calculated, along with the lower (L95) and upper (U95) 95\% confidence limits. The models are tailored for a variety of practical situations, including individual treatment efficacy, zero inflation, small sample size and potential outliers (Wang et al., 2018). 
The anthelmintic resistance status was interpreted using the method described by Lyndal-Murphy et al. (2014), and based on the World Association for the Advancement of Veterinary Parasitology (WAAVP) guidelines on anthelmintic resistance (Coles et al., 1992), considering the EPG reduction percentage and the upper and lower 95\% confidence limits.:

- Efficacious (E): percentage reduction and upper 95\% confidence limit above $95 \%$ and lower $95 \%$ confidence limit above $90 \%$.

- Confirmed anthelmintic resistance (R): percentage reduction and upper 95\% confidence limit below 95\% and lower $95 \%$ confidence limit below $90 \%$.

- Suspicion of resistance (S): neither of the above criteria fulfilled.

\section{Epidemiological questionnaire}

A structured epidemiological questionnaire was used at the farms visited, to collect information about the rearing system (extensive, intensive or semi-intensive), number of animals, type of herd exploitation, average daily milk production, deworming strategy, drugs used, frequency of drug use, routes of administration, use of endectocides and movements of animals (purchase and/or sale).

\section{Results}

The arithmetic mean (AM), minimum and maximum faecal egg counts before and after treatment, the percentage efficacy calculated based on AM, along with the lower (L95) and upper (U95) 95\% confidence limits per anthelmintic and per farm are shown in Tables 1-4. Multidrug resistance was observed in 95\% (19/20) of the farms evaluated in this study. Among these farms, 5\% (1/20) showed resistance to one drug, 20\% (4/20) to two drugs, 60\% (12/20) to three drugs and $15 \%(3 / 20)$ to all four of the drugs evaluated (Tables 1-4). Anthelmintic resistance to ivermectin and albendazole was detected in 95\% (19/20) of the herds, closantel in 75\% (15/20) and levamisole in 20\% (4/20) (Table 5).

In larval cultures, presence of five genera of gastrointestinal helminths was observed. These were predominantly Haemonchus spp. (76.7\%), which was most prevalent in all larval cultures, followed by Trichostrongylus spp. (13.2\%), Oesophagostomum sp. (8.5\%), Cooperia spp. (1.1\%) and Strongyloides sp. (0.5\%) (Table 6).

It was observed that the management system most used was semi-intensive $(75 \% ; 15 / 20)$, followed by extensive $(20 \% ; 4 / 20)$ and intensive $(5 \% ; 1 / 20)$. Dairy farms were the most frequent type among the farms studied $(40 \% ; 8 / 20)$, followed by mixed farms (35\%; $7 / 20)$ and beef farms $(25 \% ; 5 / 20)$. The number of cattle per farm ranged from 45 to 600 animals and the average daily milk production ranged from zero (beef herds) to 1700 liters.

Among the active ingredients most reported by the farmers for controlling worms, ivermectin was cited as the only drug used in $65 \%(13 / 20)$ of the farms, followed by doramectin $(20 \% ; 4 / 20)$, which are both in the group of macrocyclic lactones. In addition, ivermectin, doramectin and moxidectin were administered alone or in association also for controlling Rhipicephalus microplus and/or Haematobia irritans on 95\% (19/20) of the farms. Levamisole was mentioned in 15\% (3/20) of the farms, used separately on one farm, in association with ivermectin on another and ins association with ivermectin and doramectin on the third. There was no report of previous use of albendazole or closantel.

Anthelmintics were administered by means of injection on $100 \%$ of the farms. This took place in the entire herd at least once a year, mostly during the rainy season (January to May), on 75\% (15/20) of the farms. On the remaining $25 \%(5 / 20)$ of the farms, this was only done when verminosis was suspected and, in these cases, administration was individual.

\section{Discussion}

In the semiarid region of northeastern Brazil, the present study was the first to test the anthelmintic efficacy of four distinct pharmacological groups against bovine gastrointestinal nematodes. Multiresistance was found in $19 / 20$ herds tested. The phenomenon of multidrug resistance was also observed by Ramos et al. $(2018,2020)$ in 
Table 1. The arithmetic mean (AM), minimum (Min) and maximum (Max) faecal egg counts before (pre) and after (post) treatment of 10 animals per farm with Ivermectin 1\% (IVM) on the 20 farms (1-20) in the semiarid region of Paraíba state, Brazil. The percentage (\%) efficacy calculated based on the arithmetic group mean is provided, along with the lower (L95) and upper (U95) 95\% confidence limits. The anthelmintic resistance status (Status) is provided as confirmed anthelmintic resistance (R) or suspicion of resistance (S).

\begin{tabular}{|c|c|c|c|c|c|c|c|c|c|c|}
\hline \multirow{3}{*}{ Farm } & \multicolumn{10}{|c|}{ IVM } \\
\hline & \multicolumn{3}{|c|}{ Pre } & \multicolumn{3}{|c|}{ Post } & \multicolumn{4}{|c|}{ Efficacy } \\
\hline & $A M$ & Min & Max & AM & Min & Max & $\%$ & L95 & U95 & Status \\
\hline 1 & 240 & 150 & 850 & 120 & 0 & 400 & 50.9 & 39.6 & 88.7 & $\mathrm{R}$ \\
\hline 2 & 160 & 150 & 200 & 120 & 0 & 150 & 24.2 & 0 & 44.4 & $\mathrm{R}$ \\
\hline 3 & 650 & 150 & 2500 & 200 & 0 & 500 & 68.1 & 32.1 & 82.0 & $\mathrm{R}$ \\
\hline 4 & 155 & 150 & 200 & 155 & 0 & 450 & 0 & 0 & 0.19 & $\mathrm{R}$ \\
\hline 5 & 155 & 150 & 200 & 155 & 0 & 250 & 0 & 0 & 0.9 & $\mathrm{R}$ \\
\hline 6 & 233.3 & 150 & 500 & 133.3 & 0 & 550 & 42.7 & 12.6 & 75.9 & $\mathrm{R}$ \\
\hline 7 & 165 & 150 & 200 & 15 & 0 & 50 & 91.2 & 83.3 & 98.6 & $\mathrm{~S}$ \\
\hline 8 & 175 & 150 & 400 & 120 & 0 & 200 & 31.8 & 0 & 87.5 & $\mathrm{R}$ \\
\hline 9 & 160 & 150 & 250 & 160 & 0 & 250 & 0 & 0 & 0.7 & $\mathrm{R}$ \\
\hline 10 & 170 & 150 & 350 & 170 & 0 & 600 & 0 & 0 & 0.23 & $\mathrm{R}$ \\
\hline 11 & 155 & 150 & 200 & 155 & 0 & 200 & 0 & 0 & 0.15 & $\mathrm{R}$ \\
\hline 12 & 230 & 150 & 900 & 85 & 0 & 300 & 62.8 & 48.8 & 87.1 & $\mathrm{R}$ \\
\hline 13 & 200 & 150 & 600 & 160 & 0 & 550 & 21.9 & 0 & 37.2 & $\mathrm{R}$ \\
\hline 14 & 395 & 150 & 1650 & 130 & 0 & 900 & 66.2 & 23.2 & 78.2 & $\mathrm{R}$ \\
\hline 15 & 410 & 150 & 2450 & 90 & 0 & 400 & 76.1 & 44.1 & 91.6 & $\mathrm{R}$ \\
\hline 16 & 160 & 150 & 200 & 160 & 0 & 250 & 0 & 0 & 0.7 & $\mathrm{R}$ \\
\hline 17 & 255 & 150 & 1000 & 100 & 0 & 250 & 63.2 & 31.2 & 78.8 & $\mathrm{R}$ \\
\hline 18 & 170 & 150 & 350 & 150 & 0 & 650 & 13.7 & 0 & 32.2 & $\mathrm{R}$ \\
\hline 19 & 205 & 150 & 550 & 140 & 0 & 450 & 30.9 & 0 & 89.2 & $\mathrm{R}$ \\
\hline 20 & 465 & 150 & 3450 & 50 & 0 & 250 & 86.2 & 52.2 & 92.1 & $\mathrm{R}$ \\
\hline
\end{tabular}

the state of Rio Grande do Sul in 100\% (10/10) of the farms studied and by Soutello et al. (2007) in 20\% (5/25) of the farms assessed in the northwest of the state of São Paulo.

The results regarding ivermectin demonstrated that anthelmintic resistance was present on $95 \%(19 / 20)$ of the farms, with 36.5\% of efficacious mean for FECR. In São Paulo, Soutello et al. (2007) and Neves et al. (2014) detected anthelmintic resistance in 92\% (23/25) and 100\% (10/10), respectively, of cattle herds evaluated, after treatment with this drug. Ramos et al. (2020), in Rio Grande do Sul, also detected resistance on all the farms examined (7/7). In Argentina, resistance to ivermectin was seen on 93.5\% (58/62) (Lobayan et al., 2017) and 100\% (4/4) (Cristel et al., 2017) of the cattle farms evaluated.

In line with the lower efficacy rates of ivermectin, it was observed that macrocyclic lactones, especially avermectins, were the drugs most used for anthelmintic treatments on the farms studied, similarly to what had been observed in other studies (Pereira, 2011; Suarez \& Cristel, 2014). Soutello et al. (2007) and Ramos et al. (2018, 2020) stated that the higher rate of resistance to ivermectin, compared with other drugs, was probably related to its frequent use, and to its easy availability and ease of acquisition by farmers. Use of this drug has also been reported for controlling ticks (R. microplus) and horn flies (H. irritans), which indiscriminately boosts its use in cattle 
Table 2. The arithmetic mean (AM), minimum (Min) and maximum (Max) faecal egg counts before (pre) and after (post) treatment of 10 animals per farm with Albendazole Sulfoxide 15\% (ALB) on the 20 farms (1-20) in the semiarid region of Paraíba state, Brazil. The percentage (\%) efficacy calculated based on the arithmetic group mean is provided, along with the lower (L95) and upper (U95) 95\% confidence limits. The anthelmintic resistance status (Status) is provided as confirmed anthelmintic resistance $(\mathrm{R})$ or suspicion of resistance $(\mathrm{S})$.

\begin{tabular}{|c|c|c|c|c|c|c|c|c|c|c|}
\hline \multirow{3}{*}{ Farm } & \multicolumn{10}{|c|}{ ALB } \\
\hline & \multicolumn{3}{|c|}{ Pre } & \multicolumn{3}{|c|}{ Post } & \multicolumn{4}{|c|}{ Efficacy } \\
\hline & $A M$ & Min & Max & AM & Min & Max & $\%$ & L95 & U95 & Status \\
\hline 1 & 340 & 150 & 1950 & 145 & 0 & 650 & 57.8 & 42.3 & 78.7 & $\mathrm{R}$ \\
\hline 2 & 155 & 150 & 250 & 100 & 0 & 150 & 36.1 & 0 & 73.2 & $\mathrm{R}$ \\
\hline 3 & 355 & 150 & 1150 & 225 & 50 & 500 & 35.7 & 0 & 78.9 & $\mathrm{R}$ \\
\hline 4 & 160 & 150 & 300 & 160 & 0 & 450 & 0 & 0 & 0.17 & $\mathrm{R}$ \\
\hline 5 & 160 & 150 & 450 & 40 & 0 & 350 & 77.2 & 66.1 & 94.4 & $\mathrm{R}$ \\
\hline 6 & 300 & 150 & 500 & 160 & 0 & 600 & 42.1 & 0 & 83.1 & $\mathrm{R}$ \\
\hline 7 & 150 & 150 & 250 & 75 & 0 & 200 & 50.3 & 37.2 & 78.9 & $\mathrm{R}$ \\
\hline 8 & 155 & 150 & 250 & 90 & 0 & 150 & 42.1 & 0 & 77.2 & $\mathrm{R}$ \\
\hline 9 & 250 & 150 & 500 & 30 & 0 & 100 & 88.3 & 71.2 & 92.0 & $\mathrm{R}$ \\
\hline 10 & 185 & 150 & 500 & 185 & 0 & 1050 & 0 & 0 & 0.3 & $\mathrm{R}$ \\
\hline 11 & 200 & 150 & 350 & 65 & 0 & 100 & 67.9 & 61.2 & 91.1 & $\mathrm{R}$ \\
\hline 12 & 315 & 150 & 1100 & 65 & 0 & 200 & 78.7 & 70.4 & 89.0 & $\mathrm{R}$ \\
\hline 13 & 285 & 150 & 650 & 210 & 0 & 600 & 29.1 & 0 & 69.3 & $\mathrm{R}$ \\
\hline 14 & 245 & 150 & 900 & 160 & 0 & 550 & 22.6 & 0 & 70.1 & $\mathrm{R}$ \\
\hline 15 & 265 & 150 & 1300 & 10 & 0 & 100 & 97.7 & 87.2 & 100.0 & $S$ \\
\hline 16 & 195 & 150 & 300 & 75 & 0 & 100 & 62.3 & 50.7 & 88.2 & $\mathrm{R}$ \\
\hline 17 & 420 & 150 & 2900 & 45 & 0 & 150 & 88.3 & 79.2 & 93.2 & $\mathrm{R}$ \\
\hline 18 & 165 & 150 & 250 & 165 & 0 & 400 & 0 & 0 & 0.21 & $\mathrm{R}$ \\
\hline 19 & 205 & 150 & 400 & 65 & 0 & 150 & 71.2 & 36.4 & 94.1 & $\mathrm{R}$ \\
\hline 20 & 855 & 150 & 4900 & 135 & 0 & 450 & 81.9 & 54.3 & 89.8 & $\mathrm{R}$ \\
\hline
\end{tabular}

herds, thus generating greater pressure for selection and dissemination of resistant alleles in parasite populations (Graef et al., 2013; Neves et al., 2014; Vilela et al., 2020). These actions can promote faster development of drug resistance (Leathwick \& Luo, 2017).

For albendazole, anthelmintic resistance was also observed on $95 \%$ (19/20) of the farms, with $51.5 \%$ of efficacious mean for FECR. Ramos et al. (2020) obtained similar values for the FECR (49.8\%) and detected resistance to this drug on all the farms evaluated (7/7). On the other hand, Soutello et al. (2007) detected anthelmintic resistance on only $20 \%$ (5/25) of the farms examined, with an average FECR of 75.9\%. In Sudan, Mohammedsalih et al. (2021) reported that a reduction $(<90 \%)$ in the effectiveness of albendazole on bovine gastrointestinal nematodes had occurred.

Resistance to closantel was observed on $75 \%$ (15/20) of the farms, with $55.8 \%$ of efficacious mean for FECR, which was similar to the results obtained by Ramos et al. (2020), of 55.2\%, and Silva et al. (2017), of 45.45\%. However, Bushra et al. (2019) and Maqbool et al. (2018) found reductions of $94.44 \%$ and 100\%, respectively, in India. In the present study, despite the observed resistance, no use of this drug was reported in the herds. According to Neves (2014), the low use of closantel among cattle may be due to the fact that most products sold are for oral use, thus limiting the possibility of administering them to cattle. 
Table 3. The arithmetic mean (AM), minimum (Min) and maximum (Max) faecal egg counts before (pre) and after (post) treatment of 10 animals per farm with Closantel 25\% (CLO) on the 20 farms (1-20) in the semiarid region of Paraíba state, Brazil. The percentage (\%) efficacy calculated based on the arithmetic group mean is provided, along with the lower (L95) and upper (U95) 95\% confidence limits. The anthelmintic resistance status (Status) is provided as efficacious (E), confirmed anthelmintic resistance $(R)$ or suspicion of resistance $(S)$.

\begin{tabular}{|c|c|c|c|c|c|c|c|c|c|c|}
\hline \multirow{3}{*}{ Farm } & \multicolumn{10}{|c|}{ CLO } \\
\hline & \multicolumn{3}{|c|}{ Pre } & \multicolumn{3}{|c|}{ Post } & \multicolumn{4}{|c|}{ Efficacy } \\
\hline & $A M$ & Min & Max & AM & Min & Max & $\%$ & L95 & U95 & Status \\
\hline 1 & 210 & 150 & 750 & 70 & 0 & 250 & 67.2 & 28.3 & 83.2 & $\mathrm{R}$ \\
\hline 2 & 150 & 150 & 150 & 100 & 0 & 200 & 31.7 & 0 & 44.2 & $\mathrm{R}$ \\
\hline 3 & 170 & 150 & 250 & 25 & 0 & 100 & 86.9 & 64.7 & 97.3 & $\mathrm{~S}$ \\
\hline 4 & 180 & 150 & 250 & 40 & 0 & 50 & 77.6 & 41.3 & 94.3 & $\mathrm{R}$ \\
\hline 5 & 345 & 150 & 1900 & 25 & 0 & 200 & 91.1 & 81.4 & 97.6 & $\mathrm{~S}$ \\
\hline 6 & 266,7 & 150 & 600 & 11,1 & 0 & 50 & 94.3 & 71.4 & 100.0 & $S$ \\
\hline 7 & 165 & 150 & 350 & 35 & 0 & 200 & 79.6 & 44.4 & 91.4 & $\mathrm{R}$ \\
\hline 8 & 190 & 150 & 550 & 65 & 0 & 300 & 66.6 & 42.1 & 93.7 & $\mathrm{R}$ \\
\hline 9 & 240 & 150 & 1050 & 295 & 0 & 1000 & 0 & 0 & 0.15 & $\mathrm{R}$ \\
\hline 10 & 150 & 150 & 150 & 150 & 0 & 200 & 0 & 0 & 0.1 & $\mathrm{R}$ \\
\hline 11 & 155 & 150 & 200 & 155 & 0 & 250 & 0 & 0 & 0.14 & $\mathrm{R}$ \\
\hline 12 & 535 & 150 & 1550 & 295 & 0 & 600 & 47.2 & 0 & 83.3 & $\mathrm{R}$ \\
\hline 13 & 220 & 150 & 600 & 195 & 0 & 350 & 12.3 & 0 & 44.1 & $\mathrm{R}$ \\
\hline 14 & 490 & 150 & 1200 & 85 & 0 & 250 & 88.2 & 75.3 & 94.1 & $\mathrm{R}$ \\
\hline 15 & 210 & 150 & 350 & 15 & 0 & 50 & 96.1 & 91.4 & 100.0 & $E$ \\
\hline 16 & 185 & 150 & 500 & 90 & 0 & 600 & 47.3 & 12.1 & 71.3 & $\mathrm{R}$ \\
\hline 17 & 300 & 150 & 800 & 165 & 0 & 1150 & 49.1 & 84.6 & 91.3 & $\mathrm{R}$ \\
\hline 18 & 245 & 150 & 600 & 170 & 0 & 300 & 32.2 & 0 & 66.2 & $\mathrm{R}$ \\
\hline 19 & 375 & 150 & 1700 & 15 & 0 & 50 & 98.8 & 94.6 & 100.0 & $E$ \\
\hline 20 & 230 & 150 & 750 & 110 & 0 & 500 & 50.7 & 79.3 & 87.2 & $\mathrm{R}$ \\
\hline
\end{tabular}

Resistance to levamisole was observed on $20 \%(4 / 20)$ of the farms. Similar results regarding resistance to this drug were reported by Ramos et al. (2020), of 28\% (2/7), and Bullen et al. (2016), of 25\% (5/20), in Australia. In the present study, levamisole demonstrated the highest efficacious mean (93.1\%). Efficacious status was obtained on $55 \%(11 / 20)$ of the farms. The good efficacy of this drug in the herds tested may have resulted of its low selection pressure, as it was not used frequently by the farmers, such that it was only mentioned on 15\% (3/20) of the farms.

The Haemonchus was the most prevalent parasite genus in all larval cultures, both before and after treatments. This has also been reported in several other studies evaluating bovine gastrointestinal nematodes (Borges et al., 2015; Lobayan et al., 2017; Silva et al., 2017; Ramos et al., 2020). This nematode probably acquires resistance faster due to its high biotic potential and great genetic variability. In addition, it harbors the allele that causes decreased susceptibility to a drug (Blackhall et al., 1998; Chaudhry et al., 2015). Haemonchus placei is the species that is considered most relevant in cattle (Borges et al., 2015; Santos et al., 2015). It causes gastric hemorrhagic lesions, due to its high capacity for hematophagy (Taylor et al., 2013).

Visual estimation of the animals' weight was the practice generally used by the farmers. According to Leathwick \& Luo (2017), this can be reflected in inefficiency of the treatment, given that doses below or above those recommended 
Table 4. The arithmetic mean (AM), minimum (Min) and maximum (Max) faecal egg counts before (pre) and after (post) treatment of 10 animals per farm with Levamisole Hydrochloride $7.5 \%$ (LEV) on the 20 farms (1-20) in the semiarid region of Paraíba state, Brazil. The percentage (\%) efficacy calculated based on the arithmetic group mean is provided, along with the lower (L95) and upper (U95) 95\% confidence limits. The anthelmintic resistance status (Status) is provided as efficacious (E), confirmed anthelmintic resistance $(R)$ or suspicion of resistance $(S)$.

\begin{tabular}{|c|c|c|c|c|c|c|c|c|c|c|}
\hline \multirow{3}{*}{ Farm } & \multicolumn{10}{|c|}{ LEV } \\
\hline & \multicolumn{3}{|c|}{ Pre } & \multicolumn{3}{|c|}{ Post } & \multicolumn{4}{|c|}{ Efficacy } \\
\hline & AM & Min & Max & AM & Min & Max & $\%$ & L95 & U95 & Status \\
\hline 1 & 255 & 150 & 2150 & 0 & 0 & 0 & 100 & 100.0 & 100.0 & E \\
\hline 2 & 175 & 150 & 350 & 10 & 0 & 50 & 93.1 & 87.2 & 100.0 & $S$ \\
\hline 3 & 485 & 150 & 1500 & 40 & 0 & 250 & 95.7 & 90.1 & 99.2 & $E$ \\
\hline 4 & 230 & 150 & 800 & 0 & 0 & 0 & 100 & 100.0 & 100.0 & $\mathrm{E}$ \\
\hline 5 & 170 & 150 & 600 & 25 & 0 & 200 & 84.2 & 63.2 & 94.1 & $\mathrm{R}$ \\
\hline 6 & 261 & 150 & 950 & 6 & 0 & 50 & 98.9 & 91.3 & 100.0 & $\mathrm{E}$ \\
\hline 7 & 155 & 150 & 200 & 0 & 0 & 0 & 100 & 100.0 & 100.0 & E \\
\hline 8 & 165 & 150 & 300 & 55 & 0 & 200 & 72.3 & 37.3 & 91.7 & $\mathrm{R}$ \\
\hline 9 & 175 & 150 & 300 & 20 & 0 & 150 & 90.5 & 82.3 & 100.0 & $S$ \\
\hline 10 & 300 & 150 & 700 & 20 & 0 & 150 & 91.9 & 83.9 & 96.0 & $S$ \\
\hline 11 & 235 & 150 & 400 & 15 & 0 & 100 & 92.7 & 66.2 & 98.3 & $S$ \\
\hline 12 & 240 & 150 & 750 & 0 & 0 & 0 & 100 & 100.0 & 100.0 & E \\
\hline 13 & 165 & 150 & 300 & 45 & 0 & 150 & 73.9 & 36.4 & 89.1 & $\mathrm{R}$ \\
\hline 14 & 225 & 150 & 850 & 0 & 0 & 0 & 100 & 100.0 & 100.0 & $E$ \\
\hline 15 & 290 & 150 & 1500 & 0 & 0 & 0 & 100 & 100.0 & 100.0 & $E$ \\
\hline 16 & 180 & 150 & 350 & 0 & 0 & 0 & 100 & 100.0 & 100.0 & $E$ \\
\hline 17 & 160 & 150 & 250 & 35 & 0 & 350 & 77.6 & 36.3 & 93.2 & $\mathrm{R}$ \\
\hline 18 & 320 & 150 & 1550 & 20 & 0 & 150 & 94.2 & 90.6 & 98.0 & $S$ \\
\hline 19 & 370 & 150 & 1400 & 0 & 0 & 0 & 100 & 100.0 & 100.0 & $\mathrm{E}$ \\
\hline 20 & 978 & 150 & 3000 & 5 & 0 & 50 & 98.1 & 98.6 & 100.0 & $\mathrm{E}$ \\
\hline
\end{tabular}

Table 5. The number of farms with efficacious (E), confirmed anthelmintic resistance (R) or suspicion of resistance (S) for Ivermectin 1\% (IVM), Albendazole Sulfoxide 15\% (ALB), Closantel 25\% (CLO) and Levamisole Hydrochloride 7.5\% (LEV), and the percentage of efficacious mean (EM\%) of the anthelmintics on cattle gastrointestinal nematodes in the semiarid region of Paraíba state, Brazil.

\begin{tabular}{|c|c|c|c|c|c|c|}
\hline Treatment & $\mathbf{N}$ animals & $\mathbf{N}$ farms & EM (\%) & $\mathbf{R}$ & $S$ & $\mathbf{E}$ \\
\hline IVM & 200 & 20 & 36.5 & 19 & 1 & 0 \\
\hline ALB & 200 & 20 & 51.5 & 19 & 1 & 0 \\
\hline CLO & 200 & 20 & 55.8 & 15 & 3 & 2 \\
\hline LEV & 200 & 20 & 93.1 & 4 & 5 & 11 \\
\hline Total & & & & 57 & 10 & 13 \\
\hline
\end{tabular}

by the manufacturers might be estimated. In addition, most of the farmers (75\%; 15/20) used anthelmintics at the beginning of the rainy season. However, if the animals are treated and transferred to clean pastures, or if they are treated during the dry season, resistance can develop quickly, even if the animals receive few annual treatments 
Table 6. Percentage (\%) of cattle gastrointestinal nematodes by genus and farm recovered from larval cultures before (pre) and after (post) anthelmintic treatments with Ivermectin 1\% (IVM), Albendazole Sulfoxide 15\% (ALB), Closantel 25\% (CLO) and Levamisole Hydrochloride $7.5 \%$ (LEV) in the semi-arid region of Paraíba state, Brazil.

\begin{tabular}{|c|c|c|c|c|c|c|c|c|c|c|c|c|c|c|c|c|c|c|c|c|c|}
\hline & & \multicolumn{20}{|c|}{ Farms } \\
\hline & & \multicolumn{20}{|c|}{ IVM } \\
\hline & & 1 & 2 & 3 & 4 & 5 & 6 & 7 & 8 & 9 & 10 & 11 & 12 & 13 & 14 & 15 & 16 & 17 & 18 & 19 & 20 \\
\hline \multirow[t]{5}{*}{ Pre } & $\mathrm{H}$ & 84 & 91 & 85 & 75 & 71 & 94 & 50 & 72 & 80 & 75 & 100 & 89 & 51 & 82 & 80 & 62 & 74 & 90 & 100 & 80 \\
\hline & $\mathrm{T}$ & 10 & 6 & 9 & 16 & 14 & 4 & 40 & 13 & 18 & 25 & 0 & 3 & 49 & 0 & 4 & 23 & 4 & 5 & 0 & 19 \\
\hline & 0 & 6 & 3 & 0 & 6 & 11 & 0 & 10 & 11 & 2 & 0 & 0 & 1 & 0 & 18 & 16 & 15 & 22 & 5 & 0 & 1 \\
\hline & $C$ & 0 & 0 & 6 & 3 & 3 & 2 & 0 & 3 & 0 & 0 & 0 & 0 & 0 & 0 & 0 & 0 & 0 & 0 & 0 & 0 \\
\hline & $S$ & 0 & 0 & 0 & 0 & 1 & 0 & 0 & 1 & 0 & 0 & 0 & 7 & 0 & 0 & 0 & 0 & 0 & 0 & 0 & 0 \\
\hline \multirow[t]{7}{*}{ Post } & $\mathrm{H}$ & 94 & 74 & 78 & 95 & 97 & 61 & 93 & 75 & 98 & 70 & 60 & 100 & 81 & 85 & 76 & 95 & 74 & 74 & 94 & 58 \\
\hline & $\mathrm{T}$ & 6 & 7 & 12 & 3 & 2 & 34 & 7 & 8 & 2 & 30 & 30 & 0 & 1 & 5 & 18 & 2 & 6 & 21 & 4 & 42 \\
\hline & 0 & 0 & 9 & 5 & 2 & 1 & 5 & 0 & 17 & 0 & 0 & 0 & 0 & 18 & 10 & 6 & 3 & 20 & 5 & 2 & 0 \\
\hline & $C$ & 0 & 0 & 5 & 0 & 0 & 0 & 0 & 0 & 0 & 0 & 0 & 0 & 0 & 0 & 0 & 0 & 0 & 0 & 0 & 0 \\
\hline & $S$ & 0 & 10 & 0 & 0 & 0 & 0 & 0 & 0 & 0 & 0 & 10 & 0 & 0 & 0 & 0 & 0 & 0 & 0 & 0 & 0 \\
\hline & & \multicolumn{20}{|c|}{ ALB } \\
\hline & & 1 & 2 & 3 & 4 & 5 & 6 & 7 & 8 & 9 & 10 & 11 & 12 & 13 & 14 & 15 & 16 & 17 & 18 & 19 & 20 \\
\hline \multirow[t]{5}{*}{ Pre } & $\mathrm{H}$ & 92 & 95 & 93 & 83 & 70 & 100 & 82 & 71 & 80 & 51 & 94 & 93 & 100 & 76 & 64 & 86 & 87 & 85 & 80 & 57 \\
\hline & $\mathrm{T}$ & 2 & 5 & 2 & 9 & 13 & 0 & 8 & 14 & 19 & 49 & 4 & 2 & 0 & 0 & 30 & 7 & 3 & 15 & 20 & 33 \\
\hline & $\mathrm{O}$ & 6 & 0 & 5 & 6 & 13 & 0 & 6 & 11 & 0 & 0 & 2 & 0 & 0 & 24 & 5 & 7 & 10 & 0 & 0 & 10 \\
\hline & $C$ & 0 & 0 & 0 & 2 & 3 & 0 & 4 & 3 & 0 & 0 & 0 & 0 & 0 & 0 & 0 & 0 & 0 & 0 & 0 & 0 \\
\hline & $\mathrm{S}$ & 0 & 0 & 0 & 0 & 1 & 0 & 0 & 1 & 1 & 0 & 0 & 5 & 0 & 0 & 1 & 0 & 0 & 0 & 0 & 0 \\
\hline \multirow[t]{7}{*}{ Post } & $\mathrm{H}$ & 98 & 89 & 90 & 69 & 100 & 79 & 97 & 75 & 80 & 64 & 79 & 100 & 76 & 94 & 100 & 82 & 89 & 86 & 98 & 85 \\
\hline & $\mathrm{T}$ & 2 & 7 & 5 & 25 & 0 & 7 & 2 & 25 & 20 & 30 & 13 & 0 & 21 & 4 & 0 & 0 & 11 & 5 & 1 & 15 \\
\hline & $\mathrm{O}$ & 0 & 4 & 5 & 0 & 0 & 14 & 1 & 0 & 0 & 6 & 8 & 0 & 2 & 2 & 0 & 18 & 0 & 9 & 1 & 0 \\
\hline & C & 0 & 0 & 0 & 6 & 0 & 0 & 0 & 0 & 0 & 0 & 0 & 0 & 0 & 0 & 0 & 0 & 0 & 0 & 0 & 0 \\
\hline & $\mathrm{S}$ & 0 & 0 & 0 & 0 & 0 & 0 & 0 & 0 & 0 & 0 & 0 & 0 & 1 & 0 & 0 & 0 & 0 & 0 & 0 & 0 \\
\hline & & \multicolumn{20}{|c|}{ CLO } \\
\hline & & 1 & 2 & 3 & 4 & 5 & 6 & 7 & 8 & 9 & 10 & 11 & 12 & 13 & 14 & 15 & 16 & 17 & 18 & 19 & 20 \\
\hline \multirow[t]{5}{*}{ Pre } & $\mathrm{H}$ & 75 & 70 & 71 & 100 & 85 & 65 & 94 & 70 & 69 & 71 & 70 & 51 & 66 & 75 & 81 & 84 & 79 & 82 & 95 & 86 \\
\hline & $\mathrm{T}$ & 17 & 13 & 12 & 0 & 10 & 0 & 6 & 12 & 20 & 13 & 13 & 37 & 3 & 0 & 6 & 0 & 8 & 6 & 2 & 13 \\
\hline & 0 & 6 & 13 & 14 & 0 & 5 & 11 & 0 & 14 & 11 & 12 & 14 & 12 & 31 & 25 & 13 & 16 & 13 & 12 & 3 & 1 \\
\hline & C & 0 & 3 & 2 & 0 & 0 & 24 & 0 & 3 & 0 & 3 & 2 & 0 & 0 & 0 & 0 & 0 & 0 & 0 & 0 & 0 \\
\hline & $\mathrm{S}$ & 2 & 1 & 1 & 0 & 0 & 0 & 0 & 1 & 0 & 1 & 1 & 0 & 0 & 0 & 0 & 0 & 0 & 0 & 0 & 0 \\
\hline \multirow[t]{7}{*}{ Post } & $\mathrm{H}$ & 90 & 95 & 100 & 76 & 98 & 71 & 91 & 87 & 77 & 91 & 64 & 90 & 90 & 97 & 97 & 68 & 90 & 95 & 72 & 91 \\
\hline & $\mathrm{T}$ & 8 & 3 & 0 & 9 & 2 & 0 & 9 & 0 & 21 & 4 & 13 & 3 & 0 & 3 & 1 & 27 & 5 & 2 & 22 & 9 \\
\hline & O & 2 & 2 & 0 & 12 & 0 & 29 & 0 & 13 & 2 & 0 & 23 & 5 & 10 & 0 & 2 & 5 & 5 & 3 & 6 & 0 \\
\hline & $C$ & 0 & 0 & 0 & 3 & 0 & 0 & 0 & 0 & 0 & 0 & 0 & 0 & 0 & 0 & 0 & 0 & 0 & 0 & 0 & 0 \\
\hline & $\mathrm{S}$ & 0 & 0 & 0 & 0 & 0 & 0 & 0 & 0 & 0 & 5 & 0 & 2 & 0 & 0 & 0 & 0 & 0 & 0 & 0 & 0 \\
\hline & & \multicolumn{20}{|c|}{ LEV } \\
\hline & & 1 & 2 & 3 & 4 & 5 & 6 & 7 & 8 & 9 & 10 & 11 & 12 & 13 & 14 & 15 & 16 & 17 & 18 & 19 & 20 \\
\hline \multirow[t]{5}{*}{ Pre } & $\mathrm{H}$ & 95 & 87 & 86 & 67 & 70 & 75 & 72 & 71 & 51 & 94 & 72 & 90 & 51 & 96 & 74 & 91 & 100 & 80 & 75 & 52 \\
\hline & $\mathrm{T}$ & 4 & 13 & 9 & 18 & 14 & 0 & 6 & 14 & 16 & 3 & 13 & 0 & 32 & 0 & 5 & 7 & 0 & 19 & 25 & 39 \\
\hline & 0 & 1 & 0 & 5 & 6 & 12 & 25 & 17 & 11 & 33 & 3 & 11 & 1 & 17 & 4 & 21 & 2 & 0 & 1 & 0 & 9 \\
\hline & C & 0 & 0 & 0 & 9 & 3 & 0 & 5 & 3 & 0 & 0 & 3 & 0 & 0 & 0 & 0 & 0 & 0 & 0 & 0 & 0 \\
\hline & $S$ & 0 & 0 & 0 & 0 & 1 & 0 & 0 & 1 & 0 & 0 & 1 & 9 & 0 & 0 & 0 & 0 & 0 & 0 & 0 & 0 \\
\hline \multirow[t]{5}{*}{ Post } & $\mathrm{H}$ & - & 95 & 100 & - & 98 & 100 & - & 95 & 80 & 100 & 95 & - & 100 & - & - & - & 100 & 83 & - & 97 \\
\hline & $\mathrm{T}$ & - & 5 & 0 & - & 2 & 0 & - & 3 & 8 & 0 & 5 & - & 0 & - & - & - & 0 & 0 & - & 3 \\
\hline & 0 & - & 0 & 0 & - & 0 & 0 & - & 1 & 12 & 0 & 0 & - & 0 & - & - & - & 0 & 17 & - & 0 \\
\hline & $C$ & - & 0 & 0 & - & 0 & 0 & - & 0 & 0 & 0 & 0 & - & 0 & - & - & - & 0 & 0 & - & 0 \\
\hline & $\mathrm{S}$ & - & 0 & 0 & - & 0 & 0 & - & 0 & 0 & 0 & 0 & - & 0 & - & - & - & 0 & 0 & - & 0 \\
\hline
\end{tabular}

H: Haemonchus spp.; T: Trichostrongylus spp.; O: Oesophagostomum sp.; C: Cooperia spp.; S: Strongyloides sp. For those groups with high efficacy no coproculture was performed (-).

with anthelmintics (Martin et al., 1981; Papadopoulos et al., 2001). Therefore, management methodologies and strategies should be designed to keep parasites in refugia in herds, thereby prolonging the effectiveness of current anthelmintics and preserving susceptible nematode genotypes (Berk et al., 2016). 
Movement of animals without previous knowledge of the clinical history was a common practice reported by all the farmers. Moreover, no investigations or parasitological examinations were conducted on newly acquired animals. Both of these practices contribute to dispersion of resistant nematode populations. Bullen et al., (2016) suggested that, without prior knowledge of the farm's anthelmintic resistance status, movement of dairy cattle constitutes a considerable risk with regard to introduction of anthelmintic resistance on unaffected farms.

In addition, through PCR, Ramos et al. (2020) demonstrated the presence of co-infections of species of Haemonchus spp. that affect different cattle and sheep that share pastures. This matter deserves further study and may explain the high rates of anthelmintic resistance found on the farms studied, especially in relation to the drugs albendazole and closantel. Although no previous use of these drugs was reported in the herds evaluated, they are widely used among small ruminants and anthelmintic resistance to them in the semi-arid region of Paraíba has already been reported (Lima et al., 2010; Silva et al., 2018).

To optimize the effectiveness of anthelmintics in populations of multidrug-resistant nematodes, Ramos et al. (2016) suggested that combinations of two drugs belonging to different chemical groups should be used. However, they stressed the importance of conducting anthelmintic efficacy tests in order to choose the chemical groups to be used, as well as introduction of control measures for gastrointestinal worms within the management of cattle. Acquisition of cattle without adequate sanitary management before or after transporting them needs to be avoided. This is especially important in relation to acquisition from farms on which grazing combined with goats and/or sheep is practiced: this can be considered to be a critical point regarding worm control. Chaudhry et al. (2015) reported the first genetic confirmation of hybridization between $H$. contortus and $H$. placei in the field, thus increasing the possibility of inter-species transmission of anthelmintic resistance mutations.

\section{Conclusion}

It was concluded that the anthelmintic resistance of bovine gastrointestinal nematodes in the semiarid region of Paraíba, northeastern Brazil, is high. Multidrug resistance was observed on almost all the farms evaluated, especially in relation to the drugs ivermectin, albendazole and closantel. Levamisole was considered to be the drug with the best anthelmintic efficacy. It can be suggested that the sanitary management of cattle herds in the semiarid region should be adapted so as to avoid mass deworming without applying technical criteria. Moreover, animals should only be transported after a parasitological diagnosis has been made, especially in the case of acquisition from farms with a history of problems regarding worm control and from farms use pastures intercropped between cattle and small ruminants.

\section{Acknowledgements}

The authors acknowledge finding from CAPES (Coordenação de Aperfeiçoamento de Pessoal de Nível Superior), CNPq (Conselho Nacional de Desenvolvimento Científico e Tecnológico) and IFPB (Instituto Federal da Paraíba), for scholarship grants.

\section{References}

Almeida ACDF, Chagas JDR, Ávila LM, Marques TLP, Moraes RFF, Gomes LPM, et al. Diagnóstico e controle químico das helmintoses em bovinos: revisão de literatura. Res Soc Dev 2020; 9(11): e4089119908. http://dx.doi.org/10.33448/rsd-v9i11.9908.

Baiak BHB, Lehnen CB, Rocha RA. Anthelmintic resistance of injectable macrocyclic lactones in cattle: a systematic review and meta-analysis. Rev Bras Parasitol Vet 2019; 28(1): 59-67. http://dx.doi.org/10.1590/s1984-296120180093. PMid:30892462.

Berk Z, Laurenson YCSM, Forbes AB, Kyriazakis I. Modelling the consequences of targeted selective treatment strategies on performance and emergence of anthelmintic resistance amongst grazing calves. Int J Parasitol Drugs Drug Resist 2016; 6(3): 258271. http://dx.doi.org/10.1016/j.ijpddr.2016.11.002. PMid:27915061.

Blackhall WJ, Pouliot JF, Prichard RK, Beech RN. Haemonchus contortus: selection at a glutamate-gated chloride channel gene in ivermectin- and moxidectin- selected strains. Exp Parasitol 1998; 90(1): 42-48. http://dx.doi.org/10.1006/expr.1998.4316. PMid:9709029.

Borges FA, Borges DGL, Heckler RP, Neves JPL, Lopes FG, Onizuka MKV. Multispecies resistance of cattle gastrointestinal nematodes to long-acting avermectin formulations in Mato Grosso do Sul. Vet Parasitol 2015; 212(3-4): 299-302. http://dx.doi.org/10.1016/j. vetpar.2015.06.015. PMid:26129974. 
Bowman DD. Georgis, Parasitologia Veterinária. 9. ed. Rio de Janeiro: Elsevier; 2010.

Bullen SL, Beggs DS, Mansell PD, Runciman DJ, Malmo J, Playford MC, et al. Anthelmintic resistance in gastrointestinal nematodes of dairy cattle in the Macalister Irrigation District of Victoria. Aust Vet J 2016; 94(1-2): 35-41. http://dx.doi.org/10.1111/avj.12407. PMid:26814160.

Bushra M, Shahardar RA, Allaie IM, Wani ZA. Efficacy of closantel, fenbendazole and ivermectin against GI helminths of cattle in central Kashmir. J Parasit Dis 2019; 43(2): 289-293. http://dx.doi.org/10.1007/s12639-019-01091-w. PMid:31263335.

Cezar AS, Catto JB, Bianchin I. Controle alternativo de nematódeos gastrintestinais dos ruminantes: atualidade e perspectivas Cienc Rural 2008; 38(7): 2083-2091. http://dx.doi.org/10.1590/S0103-84782008000700048.

Chaudhry U, Redman EM, Abbas M, Muthusamy R, Ashraf K, Gilleard JS. Genetic evidence for hybridisation between Haemonchus contortus and Haemonchus placei in natural field populations and its implications for interspecies transmission of anthelmintic resistance. Int J Parasitol 2015; 45(2-3): 149-159. http://dx.doi.org/10.1016/j.ijpara.2014.09.002. PMid:25449043.

Coles GC, Bauer C, Borgsteede FH, Geerts S, Klei TR, Taylor MA, et al. World Association for the Advancement of Veterinary Parasitology (W.A.A.V.P.) methods for the detection of anthelmintic resistance in nematodes of veterinary importance. Vet Parasitol 1992; 44(1-2): 35-44. http://dx.doi.org/10.1016/0304-4017(92)90141-U. PMid:1441190.

Cristel S, Fiel C, Anziani O, Descarga C, Cetrá B, Romero J, et al. Anthelmintic resistance in grazing beef cattle in central and northeastern areas of Argentina - an update. Vet Parasitol Reg Stud Rep 2017; 9: 25-28. http://dx.doi.org/10.1016/j.vprsr.2017.04.003. PMid:31014837.

Demeler J, Van Zeveren MJ, Kleinschmidt N, Vercruysse J, Höglund J, Koopmann R, et al. Monitoring the efficacy of ivermectin and albendazole against gastro intestinal nematodes of cattle in Northern Europe. Vet Parasito/ 2009; 160(1-2): 109-115. http:// dx.doi.org/10.1016/j.vetpar.2008.10.030. PMid:19062191.

Fávero FC, Santos LB, Araújo FR, Ramünke S, Krücken J, Von Samson-Himmelstjerna G, et al. Haemonchus sp. in beef cattle in Brazil: species composition and frequency of benzimidazole resistance alleles. Prev Vet Med 2020; 185: 105162. http://dx.doi. org/10.1016/j.prevetmed.2020.105162. PMid:33099153.

Food and Agriculture Organization - FAO. Resistance Management and Integrated Parasite Control in Ruminants - Guidelines, Module 2 - Helminths: Anthelmintic resistance: Diagnnoses, Manegement and Prevention. Rome: Food and Agriculture Organization Animal Productions and Health Division; 2004.

Gasbarre LC. Anthelmintic resistance in cattle nematodes in the US. Vet Parasito/ 2014; 204(1-2): 3-11. http://dx.doi.org/10.1016/j. vetpar.2014.03.017. PMid:24798800.

Geurden T, Chartier C, Fanke J, di Regalbono AF, Traversa D, Von Samson-Himmelstjerna G, et al. Anthelmintic resistance to ivermectin and moxidectin in gastrointestinal nematodes of cattle in Europe. Int J Parasitol Drugs Drug Resist 2015; 5(3): 163-171. http://dx.doi.org/10.1016/j.ijpddr.2015.08.001. PMid:26448902.

Gordon HM, Whitlock HV. A new technique for counting nematode eggs in sheep faeces. J Counc Sci Ind Res 1939; 12(1): 50-52.

Graef J, Claerebout E, Geldhof P. Anthelmintic resistance of gastrointestinal cattle nematodes. Vlaams Diergen Tijds 2013; 82(3): 113-123. http://dx.doi.org/10.21825/vdt.v82i3.16703.

Grisi L, Leite RC, Martins JRS, Barros ATM, Andreotti R, Cançado PHD, et al. Reassessment of the potential economic impact of cattle parasites in Brazil. Rev Bras Parasito/ Vet 2014; 23(2): 150-156. http://dx.doi.org/10.1590/S1984-29612014042. PMid:25054492.

Instituto Brasileiro de Georafia e Estatística - IBGE. Anuário estatístico do Brasil [online]. Rio de Janeiro: IBGE; 2019 [cited 2021 Apr 2]. Available from: https://biblioteca.ibge.gov.br/biblioteca-catalogo?id=720\&view=detalhes.

Kreter AC, Pastre R, Bastos Filho GS. Agropecuária. Comércio exterior de produtos do agronegócio: balanço de 2020 e perspectivas para 2021. Carta de Conjuntura, $n^{\circ}$ 50, nota 29, $1^{\circ}$ trimestre de 2021 [online]. Brasília: Instituto de Pesquisa Econômica Aplicada (IPEIA); 2021 [cited 2021 Apr 4]. Available from: https://www.ipea.gov.br/portal/images/stories/PDFs/conjuntura/210331_cc_50_ nota_29_setor_externo_agro.pdf.

Leathwick DM, Luo D. Managing anthelmintic resistance - variability in the dose of drug reaching the target worms influences selection for resistance? Vet Parasito/ 2017; 243: 29-35. http://dx.doi.org/10.1016/j.vetpar.2017.05.032. PMid:28807306.

Lima WC, Athayde ACR, Medeiros GR, Lima DASD, Borburema JB, Santos EM, et al. Nematóides resistentes a alguns antihelmínticos em rebanhos caprinos no Cariri Paraibano. Pesq Vet Bras 2010; 30(12): 1003-1009. http://dx.doi.org/10.1590/S0100736X2010001200001.

Lobayan SI, Schapiro JH, Fiel CA, Zabalo MM, Roselli JG. Resistencia a los antihelmínticos en bovinos del nordeste de Corrientes (Argentina). Rev Vet 2017; 28(2): 138-140. http://dx.doi.org/10.30972/vet.2822540.

Lyndal-Murphy M, Swain AJ, Pepper PM. Methods to determine resistance to anthelmintics when continuing larval development occurs. Vet Parasitol 2014; 199(3-4): 191-200. http://dx.doi.org/10.1016/j.vetpar.2013.11.002. PMid:24314600. 
Maqbool I, Shahardar RA, Wani ZA, Allaie IM, Shah MM. Efficacy of anthelmintics against GI Helminths of cattle in Pulwama district of South Kashmir.J Pharmacogn Phytochem 2018; 7(5): 1214-1217.

Martin PJ, Lejambre LF, Claxton JH. The impact of refugia on the development of thiabendazole resistance in Haemonchus contortus. Int J Parasitol 1981; 11(1): 35-41. http://dx.doi.org/10.1016/0020-7519(81)90023-0. PMid:7228476.

Mohammedsalih KM, Krücken J, Bashar A, Juma FR, Abdalmalaik AAH, Khalafalla A, et al. Susceptible trichostrongyloid species mask presence of benzimidazole-resistant Haemonchus contortus in cattle. Parasit Vectors 2021; 14(1): 101. http://dx.doi.org/10.1186/ s13071-021-04593-w. PMid:33557939.

Neves JH, Carvalho N, Rinaldi L, Cringoli G, Amarante AFT. Diagnosis of anthelmintic resistance in cattle in Brazil: A comparison of different methodologies. Vet Parasito/ 2014; 206(3-4): 216-226. http://dx.doi.org/10.1016/j.vetpar.2014.10.015. PMid:25468021.

Neves JH. Diagnóstico de Resistência Anti-helmíntica em Bovinos [dissertation]. Botucatu: Universidade Estadual Paulista Júlio de Mesquita Filho; 2014.

O'Shaughnessy J, Earley B, Mee JF, Doherty ML, Crosson P, Barrett D, et al. Detection of anthelmintic resistance on two Irish beef research farms. Vet Rec 2014; 175(5): 120. http://dx.doi.org/10.1136/vr.102556. PMid:24902778.

Papadopoulos E, Himonas C, Coles GC. Drought and flock isolation may enhance the development of anthelmintic resistance in nematodes. Vet Parasitol 2001; 97(4): 253-259. http://dx.doi.org/10.1016/S0304-4017(01)00435-6. PMid:11390078.

Pereira JR. Práticas de controle e prevalência de helmintos gastrintestinais parasitos de bovinos leiteiros em Pindamonhangaba, São Paulo, Brasil. Rev Ciênc Agrovet 2011; 10(1): 16-22.

Ramos F, Marques CB, Reginato CZ, Bräunig P, Osmari V, Fernandes F, et al. Field and molecular evaluation of anthelmintic resistance of nematode populations from cattle and sheep naturally infected pastured on mixed grazing areas at Rio Grande do Sul, Brazil. Acta Parasitol 2020; 65(1): 118-127. http://dx.doi.org/10.2478/s11686-019-00137-6. PMid:31721057.

Ramos F, Marques CB, Reginato CZ, Rodrigues FS, Sangioni LA, Vogel FSF, et al. Economic viability of anthelmintic treatment in naturally infected beef cattle under different nutritional strategies after weaning. Parasito/ Res 2018; 117(12): 3993-4002. http:// dx.doi.org/10.1007/s00436-018-6108-z. PMid:30302586.

Ramos F, Portella LP, Rodrigues FS, Reginato CZ, Pötter L, Cezar AS, et al. Anthelmintic resistance in gastrointestinal nematodes of beef cattle in the state of Rio Grande do Sul, Brazil. Int J Parasitol Drugs Drug Resist 2016; 6(1): 93-101. http://dx.doi.org/10.1016/j. ijpddr.2016.02.002. PMid:27054068.

Roberts FHS, O'Sullivan JP. Methods for egg counts and larval cultures for strongyles infesting the gastro-intestinal tract of cattle. Aust J Agric Res 1950; 1(1): 99-102. http://dx.doi.org/10.1071/AR9500099.

Rose H, Rinaldi L, Bosco A, Mavrot F, de Waal T, Skuce P, et al. Widespread anthelmintic resistance in European farmed ruminants: a systematic review. Vet Rec 2015; 176(21): 546. http://dx.doi.org/10.1136/vr.102982. PMid:25762583.

Santos PR, Baptista AAS, Leal LS, Moletta JL, Rocha RA. Nematódeos gastrintestinais de bovinos - revisão. Rev Cient Elet Med Vet 2015; 24: 1-15.

Silva FF, Bezerra HMFF, Feitosa TF, Vilela VLR. Nematode resistance to five anthelmintic classes in naturally infected sheep herds in Northeastern Brazil. Rev Bras Parasito/ Vet 2018; 27(4): 423-429. http://dx.doi.org/10.1590/s1984-296120180071. PMid:30427525.

Silva WW, Delfino LJB, Medeiros MC, Silva JP. Multiple resistances of gastrointestinal nematodes to anthelmintic groups in cattle of semiarid of Paraíba, Brazil. Acta Bras 2017; 1(2): 29-32. http://dx.doi.org/10.22571/Actabra12201735.

Soutello RGV, Seno MCZ, Amarante AFT. Anthelmintic resistance in cattle nematodes in northwestern São Paulo State, Brazil. Vet Parasito/ 2007; 148(3-4): 360-364. http://dx.doi.org/10.1016/j.vetpar.2007.06.023. PMid:17656022.

Suarez VH, Cristel SL. Risk factors for anthelmintic resistance development in cattle gastrointestinal nematodes in Argentina. Rev Bras Parasitol Vet 2014; 23(2): 129-135. http://dx.doi.org/10.1590/S1984-29612014045. PMid:25054489.

Taylor MA, Coop RL, Wall RL. Veterinary parasitology. 3rd ed. Oxford: Wiley- Blackwell; 2013.

Vilela VLR, Feitosa TF, Bezerra RA, Klafke GM, Riet-Correa F. Multiple acaricide-resistant Rhipicephalus microplus in the semiarid region of Paraíba State, Brazil. Ticks Tick Borne Dis 2020; 11(4): 101413. http://dx.doi.org/10.1016/j.ttbdis.2020.101413. PMid:32173298.

Wang C, Paul M. eggCounts: Hierarchical Modelling of Faecal Egg Counts. R package version 2.3 [software]. Vienna: R Foundation for Statistical Computing; 2018. Available from: https://CRAN.R-project.org/package=eggCounts

Wang C, Torgerson PR, Kaplan RM, George MM, Furrer R. Modelling anthelmintic resistance by extending eggCounts package to allow individual efficacy. Int J Parasitol Drugs Drug Resist 2018; 8(3): 386-393. http://dx.doi.org/10.1016/j.jjpddr.2018.07.003. PMid:30103206. 